\title{
Removal of Heavy Metal by lon Exchange Using Bentonite Clay
}

\author{
Shaymaa Talib Hussain', Seroor Atalah Khaleefa Ali ${ }^{*}$ \\ 1 Graduate Student, Environmental Engineering Department, University of Mustansiriyah, Baghdad, Iraq \\ 2 Corresponding Author and Assistant Professor, Department of Environmental Engineering, College of \\ Engineering, Mustansiriyah University, Baghdad, Iraq \\ * Corresponding author's e-mail: dr.sroor@uomustansiriyah.edu.iq; seroor909ali@gmail.com
}

\begin{abstract}
Bentonite clay was utilized in this research as adsorbent element to remove the lead and copper ions from wastewater. Series of tests were performed at multiple parameters, such as $\mathrm{pH}$ solution, initial concentration of lead and copper ions, adsorbent mass, and contact time. The greatest removal was attained at $\mathrm{pH}$ 5, adsorbent weight of $0.5 \mathrm{~g}$, initial heavy metal concentration of $10 \mathrm{mg} / 1$, and a contact time of 60 minutes. The results revealed that bentonite clay is suitable in the removal of metal ions from polluted water. The ion exchange rate of lead was faster than that of copper. The isotherm for the adsorption of the lead and copper ions on bentonite clay was confirmed by the Freundlich and Langmuir isotherms which offered good consequences. The results indicated that bentonite was utilized as an efficient ion exchange element for the removal of heavy metal ions from polluted water. Fourier Transformed Infrared Spectrophotometer (FTIR) images of bentonite clay before and after adsorption showed the imbibition of metal ions by bentonite clay.
\end{abstract}

Keywords: bentonite, lead ions, copper ions, adsorption, wastewater, Freundlich and Langmuir isotherms

\section{INTRODUCTION}

Heavy metal is one of the most dangerous environmental issues threatening life on the Earth. Heavy metals are determined environmental pollutants that cannot be eliminated (Lacin et al., 2005; Helena et al., 2011). The continuous discharge of pollutants was due to the increase in the generation of human waste, which is mainly produced by industries, leading to the deterioration of the water quality. The most dangerous pollutants which influence the biological performance of some organisms are mineral species from industrial waste, which reduce the ability of water for self-purification, interfere with metabolic cycle leading to an increase in the minerals concentration within the food chain (Galindo et al., 2013). Serious soil and water pollution were caused by several toxic heavy metals discharged into the environment as industrial wastes (Nassef et al., 2017; Abbas et al., 2019). The heavy metals contamination was known as a possible threat to soil, water, and air.
One of the heavy metals which is considered in this research is copper $\left(\mathrm{cu}^{+2}\right)$. Copper is a widely used material (Mnasri-Ghnimi and Frini-Srasra, 2019). Although it is essential for human health, it poses a health hazard when it exceeds the permissible concentration, causing kidney damage, anemia, stomach intestinal distress, coma, and eventual death (Lacin et al., 2005). $\mathrm{Cu}^{+2}$ causes many skin diseases, including itching, dermatitis, and keratosis of soles to hands and feet (Benzaoui et al., 2017). When the concentration of this trace element is $0.80 \mathrm{mg} / \mathrm{l}$ in water, it may be responsible for the pink disease among infants, in addition to being a carcinogen for animals.

Lead $\left(\mathrm{Pb}^{+2}\right)$, another heavy metal investigated in this paper, is very poisonous as it harmfully affects kidneys and red blood cells of the human nervous system (Acharya et al., 2009; Potgieter et al., 2006; Mutter et al., 2017). Due to its existence in the environment as gases resulting from burning materials with lead content, fuels, soil also water contamination via lead smelting effluents, battery industries, paint, paper, and mining, it is 
considered one of the most prominent ecological pollutants (Mohan and Pittman, 2006; Hannachi et al., 2013).

Numerous methods have been applied for the removal of heavy metals from aqueous solutions, including reverse osmosis, ultrafiltration, electro-dialysis, solvent extraction, chemical precipitation, ion exchange, and adsorption (Fu and Wang, 2011; Jiang et al., 2009). Adsorptions of heavy metals from aqueous solutions have been examined using different adsorbents (Gusain et al., 2014; Karapinar and Donat, 2009). One of these adsorbents includes clays (especially bentonite). Clay is considered as low-cost adsorbent. Clay has gained great attention in heavy metals sorption from polluted water as a result of their acceptability and applicability (Zuzana and Michaela, 2015).

Bentonite is natural clay with silicate layers of $2: 1$. The clay surface has a negative charge due to replacement of aluminum and magnesium for silicon and aluminum, in a tetrahedral and octahedral layer, respectively. An important property of bentonite, is its great ability to absorb a cation. The essential component of bentonites was montmorillonite, which is a 2:1 mineral with one octahedral sheet and two silica sheets, creating a layer. The Van der Waals forces are acting on these layers keeping them together. Water can easily penetrate these layers and cations balance as a result of these weak forces (Ding et al., 2009).

Numerous studies were conducted by using bentonite clay as adsorbent of heavy elements. Karapinar and Donat (2009) considered the adsorption method of cadmium and copper. The results indicated the highest removal efficiency for cadmium and copper were 87.0 and $84.5 \%$, respectively, onto natural bentonite. Bertagnolli et al. (2011) achieved the removal percentage of $50.0 \%$ for adsorption of copper in porous beds using Brazilian bentonite clay. Neto et al. (2012) estimated copper removal with bentonite clay, attaining $81.0 \%$ for raw clays and $42.0 \%$ for calcined bentonite clays. Hannachi et al. (2013) performed several experiments to evaluate the possibility of using bentonite as adsorbent material to remove $\mathrm{Pb}^{+2}$ from aqueous solutions. The contact time, influence of $\mathrm{pH}$, initial concentration of metal, and adsorbent mass to adsorb $\mathrm{Pb}^{+2}$ were considered. Different kinetic models were used for studying kinetics of $\mathrm{Pb}^{+2}$ adsorption rate on bentonite clay. Experimental data were applied on different isotherm equations to investigate the best one for associating the experimental data. The Fourier Transformed Infrared Spectrophotometer (FTIR) was applied to describe and discriminate position of $\mathrm{Pb}^{+2}$ cations on bentonite clay.

Furthermore, Inglezakisa (2019) investigated the capability of clinoptilolite, naturalist zeolite as well as bentonite in removing $\mathrm{Pb}^{+2}$ from aquatic solutions through batch devices with a high 120.0 minute of contact time. The adsorption experiment of $\mathrm{Pb}^{+2}$ was performed with initial metal concentration $1,036 \mathrm{mg} / \mathrm{l}, \mathrm{pH}=4$, and solid to liquid ratio of $2 \mathrm{~g} / 100 \mathrm{ml}$. The mixing speed varied from $0,100,200$, to $500 \mathrm{rpm}$, particle diameter from 2.5 to $5.0 \mathrm{~mm}$ dust, and temperature of $28.0^{\circ} \mathrm{C}, 45.0^{\circ} \mathrm{C}$, and $60.0^{\circ} \mathrm{C}$, the acidity effect of aqueous solution was tested as well. Bentonite was active in the removal of $\mathrm{Pb}^{+}$ ${ }^{2}$ from clinoptilolite, under the same experimental conditions. At the agitation speed of $100 \mathrm{rpm}$ and ambient temperature, the removal of $\mathrm{Pb}^{+2}$ by bentonite reached $100 \%$. In turn, at $60^{\circ} \mathrm{C}$ without agitation, it was about $90 \%$. Otherwise, the maximum removal via clinoptilolite reached $55 \%$. Granular clinoptilolite was less effective than Clinoptilolite dust. Agitation and the uptake of $\mathrm{Pb}^{+2}$ affected by temperature especially in the case of granular clinoptilolite from 2.5 to $5.0 \mathrm{~mm}$. Finally, the lead removal by minerals could be affected by the acidity of the aqueous solutions. As the $\mathrm{pH}$ value increased from 1 to 4 , the removal of $\mathrm{Pb}^{+2}$ improved too.

The aim of this study was to evaluate the capability of bentonite clay to adsorb $\mathrm{Pb}^{+2}$ also $\mathrm{Cu}^{+2}$ by ion exchange from aqueous solutions and to explore the impact of $\mathrm{pH}$, mass of adsorbent, initial metal concentrations, and contact time on the adsorption these minerals by the bentonite clay.

\section{METHODS AND MATERIALS}

\section{Preparation of Bentonite}

In this study, pure bentonite was used as adsorbent material. It was attained from the local market in Baghdad city. The samples of bentonite were dried on air at room temperature and sieved with a $(1.18 \mathrm{~mm})$ diameter. The X-Ray Fluorescence (XRF) was performed to characterize the dried samples. The chemical compositions are listed in Table 1. The highest chemical component $50.5 \%$ for $\mathrm{SiO}_{2}$ and the lowest one 
was 0.001 for $\mathrm{Y}_{2} \mathrm{O}_{3}$. The physical analysis of bentonite clay found that cation exchange capacity (CEC) and surface area were $104 \mathrm{meq} / 100 \mathrm{~g}$ and $67.6 \mathrm{~m}^{2} / \mathrm{g}$, respectively.

\section{Instrument}

The functional group illustration of the soil sample was carried out by Fourier Transformed Infrared Spectrophotometer (FTIR). The FTIR spectra of the samples were placed in wave length varying in the range of $4000-400 \mathrm{~cm}^{-1}$. The concentration of metals was investigated by Atomic Absorption Spectrophotometry (AAS). The chemical composition of the clay soil sample was established using X-ray Fluorescence (XRF). Brunauer-Emmett-Teller (BET) method was utilized to measure surface area using nitrogen gas adsorption. The $\mathrm{NH}_{4} \mathrm{Cl}-50 \%$ and $\mathrm{CH}_{3} \mathrm{CH}_{2} \mathrm{OH}$ were found by CEC.

\section{Batch Adsorption Study of Heavy Metals}

The stock solution of lead and copper ions were prepared using lead nitrate $\mathrm{Pb}\left(\mathrm{NO}_{3}\right)_{2}$ and copper nitrate trihydrate $\mathrm{Cu}\left(\mathrm{NO}_{3}\right)_{2} \cdot 3 \mathrm{H}_{2} \mathrm{O}$. One thousand in $\mathrm{mg} / \mathrm{l}$ was obtained by dissolving $1.6 \mathrm{gm}$ of $\mathrm{Pb}\left(\mathrm{NO}_{3}\right)_{2}$ in $1000 \mathrm{ml}$ deionized water and $3.8 \mathrm{gm}$ of $\mathrm{Cu}\left(\mathrm{NO}_{3}\right)_{2} \cdot 3 \mathrm{H}_{2} \mathrm{O}$ in $1000 \mathrm{ml}$ deionized water, as shown in Figure 1. The essential concentration in each experiment of $\mathrm{Cu}^{+2}$ and $\mathrm{Pb}^{+2}$ was obtained by diluting stock solution. The batch equilibrium tests were conducted to assess ideal $\mathrm{pH}$, mass of clay, contact time and initial concentration of heavy metals. A $500 \mathrm{ml}$ flask with $300 \mathrm{ml}$ heavy metals solution of $10 \mathrm{mg} / \mathrm{l}$ was performed using electrical balance weight of clay adsorbent and $0.5 \mathrm{gm}$ was added into different flask. The mixture was shaken at $200 \mathrm{rpm}$ in the shaker with contact time

Table 1. Chemical analysis of bentonite clay by XRF

\begin{tabular}{|c|c|c|c|}
\hline Composition & Content, \% & Composition & Content, \% \\
\hline $\mathrm{SiO}_{2}$ & 50.459 & $\mathrm{MnO}$ & 0.021 \\
\hline $\mathrm{Al}_{2} \mathrm{O}_{3}$ & 33.235 & $\mathrm{SrO}$ & 0.018 \\
\hline $\mathrm{CaO}$ & 8.043 & $\mathrm{ZnO}$ & 0.010 \\
\hline $\mathrm{Fe}_{2} \mathrm{O}_{3}$ & 5.581 & $\mathrm{ZrO}_{2}$ & 0.008 \\
\hline $\mathrm{K}_{2} \mathrm{O}$ & 1.535 & $\mathrm{CuO}$ & 0.005 \\
\hline $\mathrm{TiO}_{2}$ & 0.501 & $\mathrm{NiO}$ & 0.003 \\
\hline $\mathrm{SO}_{3}$ & 0.497 & $\mathrm{MoO}_{3}$ & 0.003 \\
\hline $\mathrm{V}_{2} \mathrm{O}_{5}$ & 0.040 & $\mathrm{Y}_{2} \mathrm{O}_{3}$ & 0.001 \\
\hline $\mathrm{Cr}_{2} \mathrm{O}_{3}$ & 0.030 & $\mathrm{CO}_{2}$ & 0.010 \\
\hline
\end{tabular}

of $30 \mathrm{~min}$. The adsorbent and the solution were separated through filter paper $(0.45 \mu \mathrm{m})$ diameter and then analyzed by AAS to determine the final concentration of heavy metals. The effect of $\mathrm{pH}$ on the heavy metal ions removal using ion exchange was studied in the range $(5,7$, and 9) by adding $0.1 \mathrm{~N} \mathrm{HCL}, 0.1 \mathrm{~N} \mathrm{NaOH}$ to obtain the desired $\mathrm{pH}$ checked by a $\mathrm{pH}$-meter. The amount of clay were $0.2,0.5,1,1.5$, and $2 \mathrm{gm}$, the concentrations of heavy metals ions were 10, 20, 30, 40 , and 50, and contact times were $15,30,45$, 60,90 , and 120 minutes. The removal percentage is estimated as follows:

$$
R(\%)=\frac{\left(C_{O}-C_{e}\right)}{C_{O}} * 100
$$

where: $R$ is removal efficiency in \%; and $C_{e}$ and $C_{o}$ are equilibrium and initial concentrations in $\mathrm{mg} / \mathrm{g}$, respectively. Then, the capacity of adsorption in $\mathrm{mg} / \mathrm{g}$ can be found from the following:

$$
q_{e}=\frac{V\left(C_{O}-C_{e}\right)}{M}
$$

where: $q_{e}$ is concentration of the adsorbed metal ions in $\mathrm{mg} / \mathrm{g}$;

$M$ is mass of adsorbent in $\mathrm{g}$;

$V$ is solution volume in $l$.

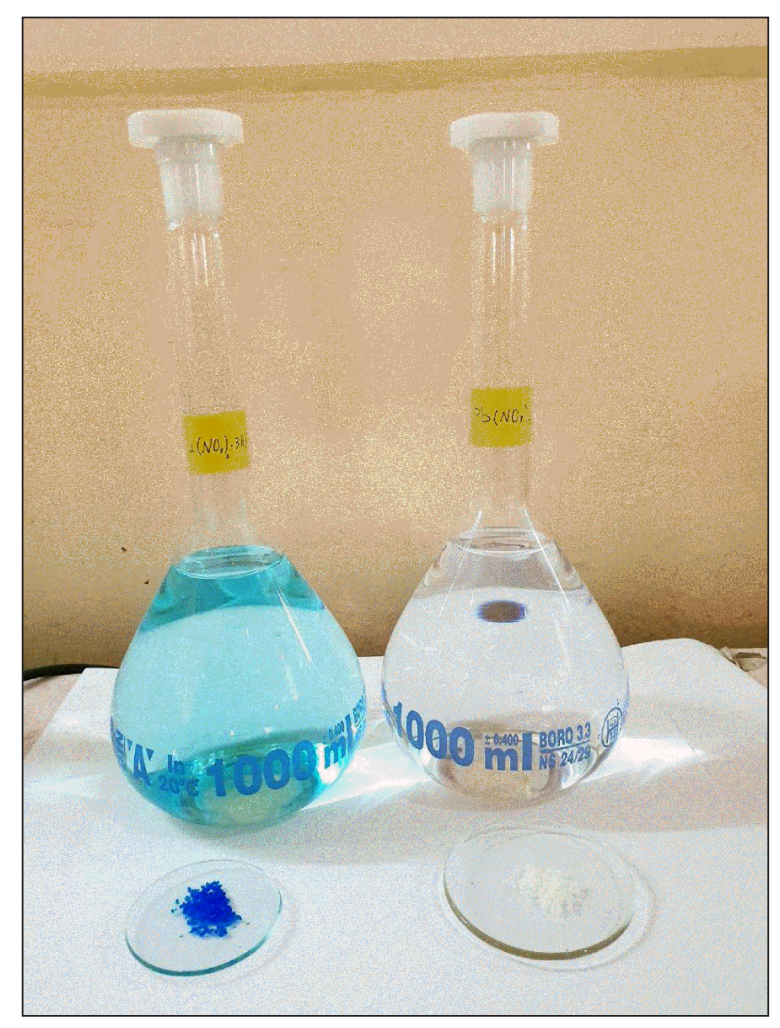

Figure 1. Heavy metals stock solutions 


\section{RESULTS AND DISCUSSION}

\section{Influence of $\mathrm{pH}$}

In order to examine the influence of $\mathrm{pH}$ on the removal of lead and copper by bentonite clay, multiple $\mathrm{pH}$ levels ranging from 3 to 5 and 7 to 9 were studied as shown in Figure 2, with a constant clay mass of $0.5 \mathrm{gm}$, initial concentration of heavy metals of $10 \mathrm{mg} / 1,30 \mathrm{~min}$ contact time, and $300 \mathrm{ml}$ volume at room temperature. The main mechanisms of the adsorption properties on bentonites are adsorption and ion exchange. At $\mathrm{pH}$ of 5 , the competition between the metal ions and $\mathrm{H}+$ ions reduces on the active sites of the adsorbents clay because the concentration of $\mathrm{H}+$ ions in solution decreases while attraction between metal ion and the surface of clay increases through electrostatic force. At these $\mathrm{pH}$ levels, the negotiable cations, present at the redeemable positions in bentonite structure (such as sodium, potassium, calcium and magnesium) were exchanged for lead and copper cations in the metal solutions. In the present study, a $\mathrm{pH}$ value of 5.0 was used for further tests to avoid the precipitation of metal ions. When $\mathrm{pH}$ values more than 5.0 , the removal efficiency rises because metal ions precipitate from the solution in the form of hydroxides (Ogbu, 2019).

\section{Effect of Adsorbent Mass}

Clay was utilized to find the quantities acceptance of metal ion. The number of sites existing

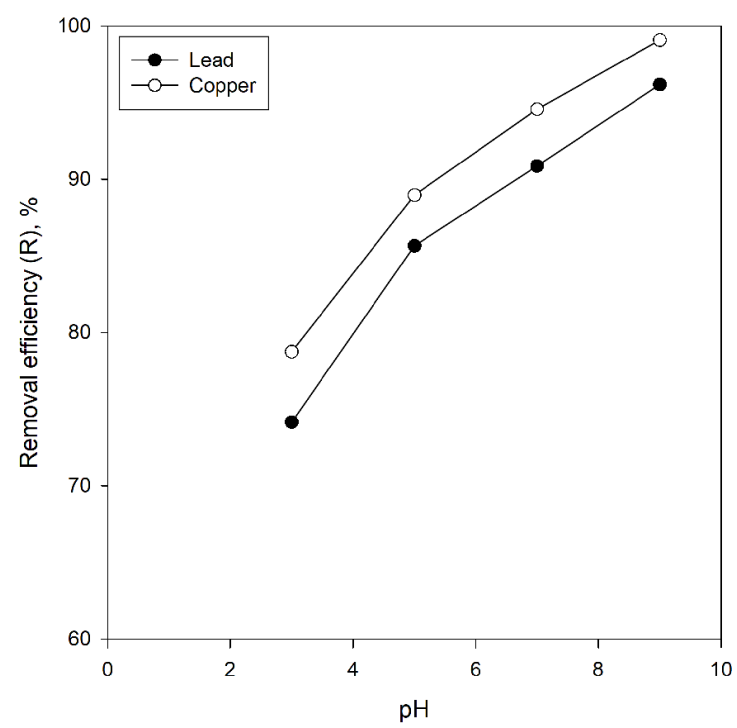

Figure 2. Influence of $\mathrm{pH}$ on removal efficiency to lead and copper ions by bentonite clay for holding metals in a solution affects by the adsorbent mass removal of copper and lead ions by the adsorbent clay was studied with different mass from ( 0.2 to $2 \mathrm{gm})$, keeping each metal ion concentration $10(\mathrm{mg} / \mathrm{l}), \mathrm{pH} 5$ and $30 \mathrm{~min}$ mixing speed as shown in Figure 3. It was noticed that the removal efficiency on bentonite clay increased from 78.8 to $87.6 \%$ and 80.1 to $89 \%$ to copper and lead ions, respectively. The increase in the removal percentage with an increase in the adsorbent mass was due to availability of high exchangeable sites in clay structure. These results correspond to those obtained by Melichov and Hromada (2012). The absorption of heavy metal ions increases along with the amount of bentonite, due to the accessibility of a greater surface area which contains a greater number of ion exchange locations at a time when the initial metal concentration is constant, resulting in a higher removal efficiency.

\section{Influence of Initial Metal Concentration}

In the adsorption experiments, the initial metal ion concentration is very important, so the concentrations of lead and copper ions were selected from 10 to $50 \mathrm{mg} / \mathrm{l}$ for bentonite clay. The experiments were performed with optimum $\mathrm{pH}$, contact time and adsorbent mass were kept at 5, $30 \mathrm{~min}$. and $1,0.5 \mathrm{~g}$ to copper and lead ions, sequentially. Figure 4 displays the impact of initial concentrations of metal ions on the adsorption of heavy metals. The results showed the removal efficiency decrease with increasing initial concentration from

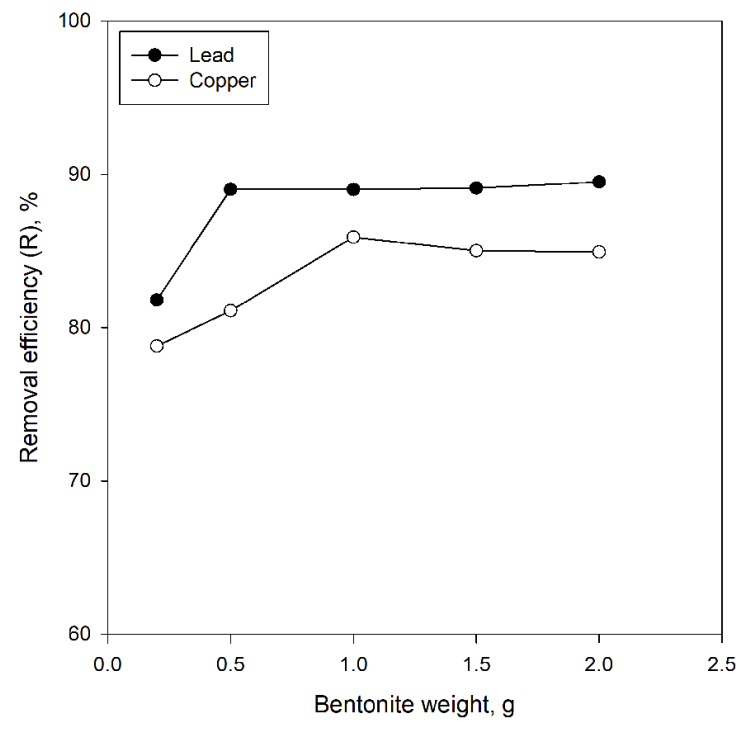

Figure 3. Influence of bentonite clay weights on the removal efficiency of lead and copper ions 


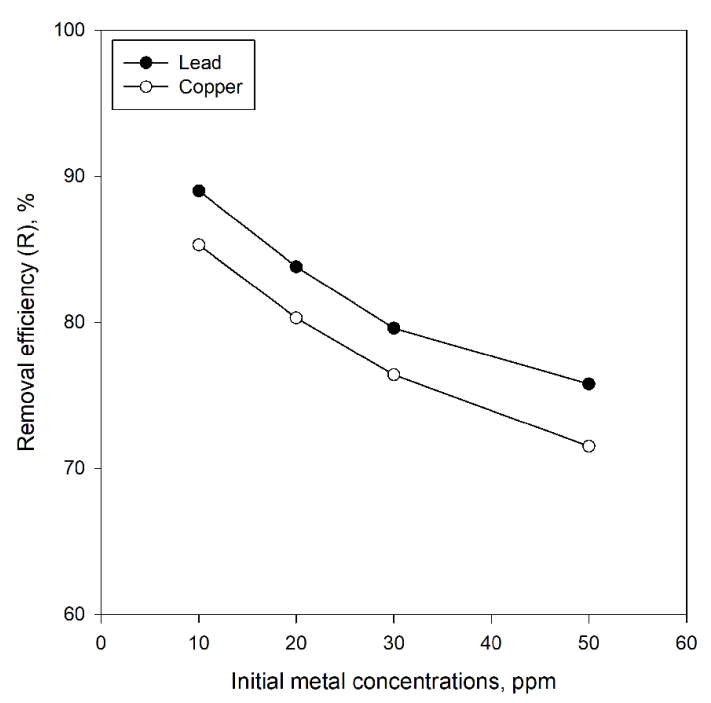

Figure 4. Influence of initial metal concentrations on the removal efficiency of copper and lead ions using bentonite clay

87.7 to $76.88 \%$ and 89 to $75.76 \%$ on bentonite clay for copper and lead ions, respectively. This was due to that the active sites in bentonite clay were saturated, so more metal ions would be left un-adsorbed at higher concentrations. At lower concentrations, more active sites on the adsorbent would be available to adsorb the metal ions (Jiang et al., 2009; Melichov and Hromada, 2012).

\section{Influence of Contact Time}

The contact time affecting on ion exchange of metal ions across bentonite was investigated by changing contact time from 15 to $120 \mathrm{~min}$ (Figure 5). The $\mathrm{pH}$, clay mass, and initial metal concentration were kept constant at 5, 1 and $0.5 \mathrm{~g}$ for $\mathrm{Cu}^{+2}$ and $\mathrm{Pb}^{+2}$ ions, respectively, $300 \mathrm{rpm}$, and $10 \mathrm{mg} / \mathrm{l}$ of $300 \mathrm{ml}$ volume, sequentially, at room temperature. Figure 5 shows that the percentage removal of metal ion sorbed increased along with time until equilibrium was reached at 30.0 minutes. The increase in contact time had no significant effect. At first stage, the ion exchange was fast due to the large number of active sites existing on the adsorbent clay which saturated with the passage of time until equilibrium was reached. The high percentage removal achieved on bentonite was 87.7 and $89.0 \%$ for copper and lead, respectively.

\section{Adsorption Isotherms}

Equilibrium adsorption is generally defined by an isotherm equation which the surface properties

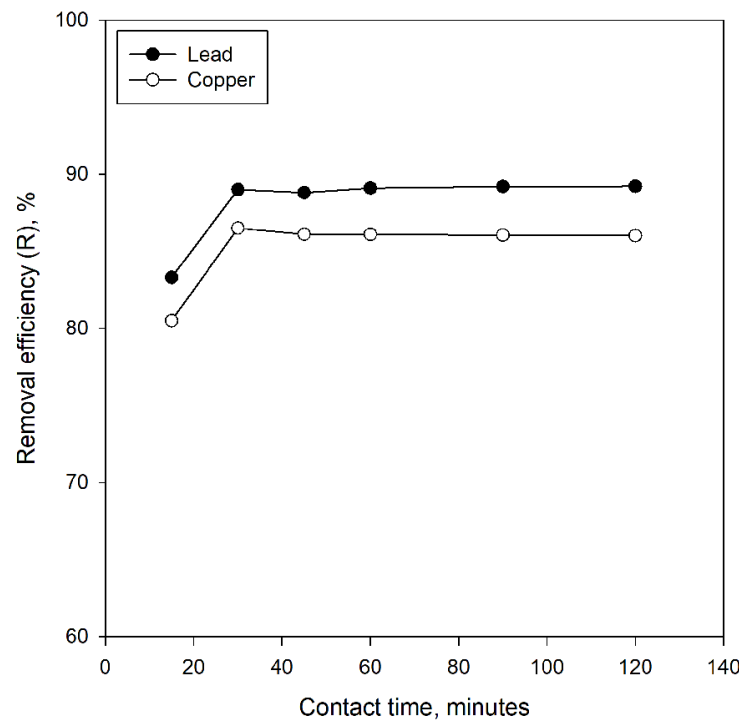

Figure 5. Influence of contact time on the removal efficiency of copper and lead ions using bentonite clay

and attraction of the adsorbent expressed by its parameters. The Freundlich and Langmuir isotherms were applied to found rapport between the amount of $\mathrm{Pb}^{+2}$ and $\mathrm{Cu}^{+2}$ ions sorbed by bentonite clay and their equilibrium concentrations in aqueous solution. The Langmuir isotherm was built on supposition one monolayer only shaped through reaction, existence corresponding positions, fixity of adsorbate and absence the interaction between adsorbate-adsorbent. The Langmuir isotherm reflects high sorption while the Freundlich isotherm reflects infinity position (Ugwu and Igbokwe 2019) when variance between two models. The Langmuir equation (Figures 6 and 7) is described as shown:

$$
\frac{C_{e}}{q_{e}}=\frac{1}{\left(q_{m} * K_{L}\right)}+\frac{C_{e}}{q_{m}}
$$

where: $q_{m}$ is the monolayer adsorption capacity in $\mathrm{mg} / \mathrm{g}$,

$K_{L}$ is the Langmuir equilibrium constant in $1 / \mathrm{mg}$. The Freundlich isotherm (Figures 6 and 7) is explained as:

$$
\log q_{e}=\log K_{F}+\frac{1}{n \log C_{e}}
$$

where: $K_{F}$ is Freundlich adsorption isotherm constant, indicating the amount of adsorption, and

$n$ is the Freundlich constant associated with adsorption intensity.

The correlation factor for the Langmuir and Freundlich models are 0.94 and 0.90 for lead and 
a) Langmuir

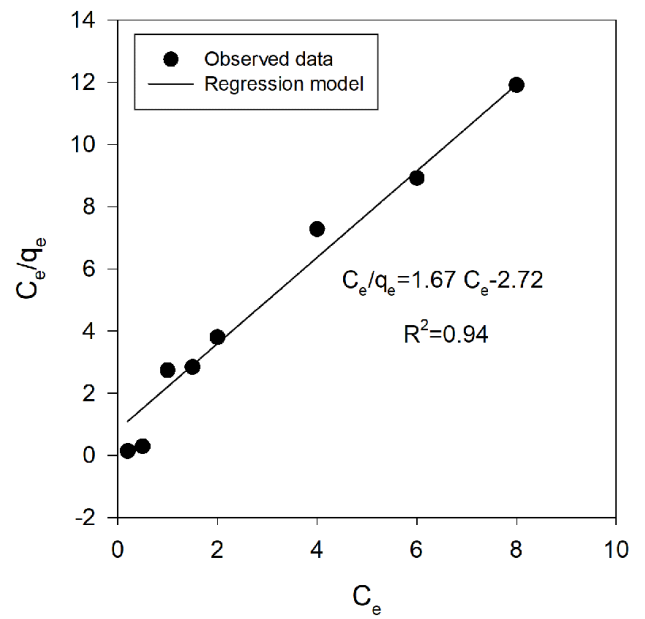

b) Freundlich

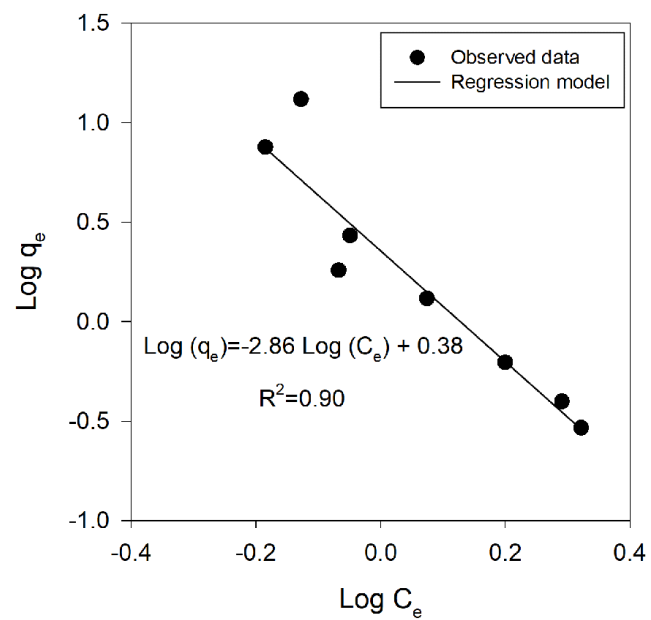

Figure 6. Lead ions modeled by the Langmuir and Freundlich isotherm formulas (linear equations)

a) Langmuir

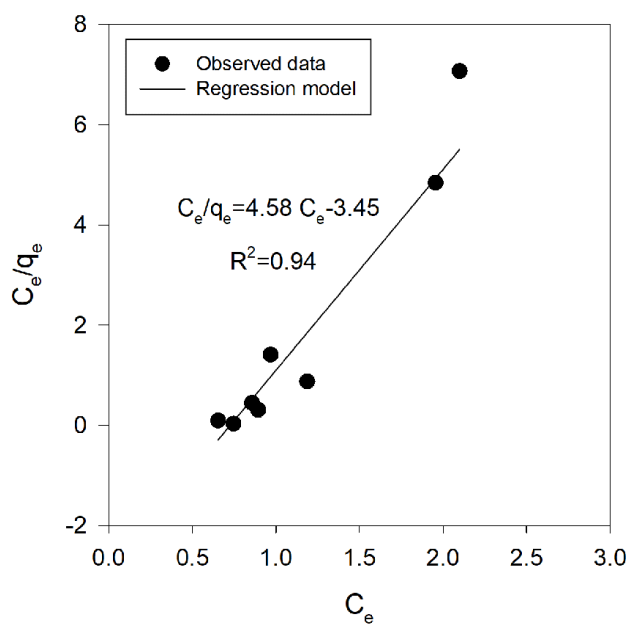

b) Freundlich

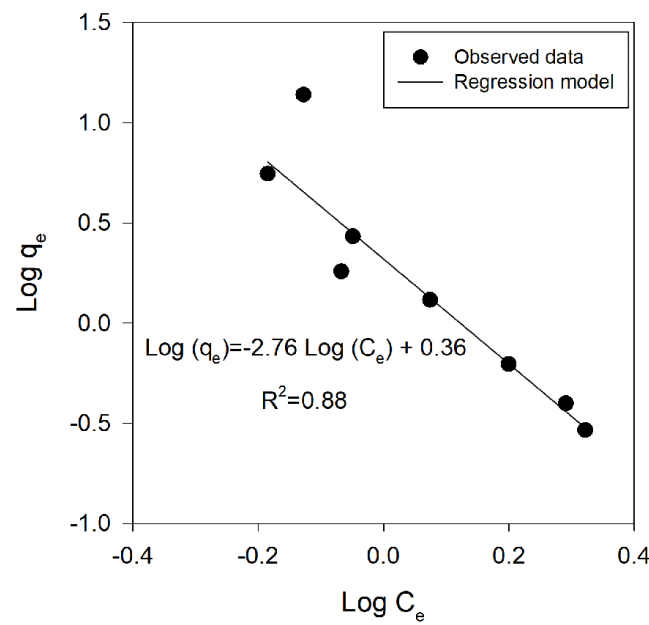

Figure 7. Copper ions modeled by the Langmuir and Freundlich isotherm formulas (linear equations)

0.94 and 0.88 for copper, respectively, as shown in Table 2. Thus, the Langmuir isotherm describes well the adsorption of $\mathrm{Pb}^{+2}$ and $\mathrm{Cu}^{+2}$ on bentonite clay and adsorption process occurs. There is a monolayer on the regular distribution of active sites on bentonite clay surface.

\section{FTIR Analysis}

The FTIR Spectra of the bentonite, in the range of 400 to $4000 \mathrm{~cm}^{-1}$ was performed to approve the presence of functional groups that might be responsible for the adsorption process and presented in Figures 8 and 9 . The absorption peaks at 3624 to $3406 \mathrm{~cm}^{-1}$ were attributed to $\mathrm{OH}^{-}$stretching of the Al$\mathrm{OH}$ groups. However, a broad band at $2513.25 \mathrm{~cm}^{-1}$ in the spectrum of clay clarifies the possibility of water hydration $(\mathrm{H}-\mathrm{O}-\mathrm{H})$ in the adsorbent.
The bands at 1795 to $1435 \mathrm{~cm}^{-1}$ corresponded to the presence of $\mathrm{C}-\mathrm{H}$ and $\mathrm{C}=\mathrm{C}$ for organic components of clay soil. The band near $1037.7 \mathrm{~cm}^{-1}$ to $711.73 \mathrm{~cm}^{-1}$ is due to $\mathrm{Si}-\mathrm{O}$ stretching in tetrahedral sheets. The bands at 694.37 to $424.34 \mathrm{~cm}^{-1}$ result from $\mathrm{Si}-\mathrm{O}-\mathrm{Al}$ bending. Bentonite clay basically unchanged for the $\mathrm{Pb}$ (II) (3628.10,

Table 2. Parameters of the Langmuir and Freundlich isotherm according ion exchange to metal ions by bentonite clay

\begin{tabular}{|l|c|c|c|}
\hline \multicolumn{1}{|c|}{ Models } & Parameter & $\mathrm{Pb}^{+2}$ & $\mathrm{Cu}^{+2}$ \\
\hline \multirow{2}{*}{$\begin{array}{l}\text { Langmuir } \\
\text { Isotherm }\end{array}$} & $\mathrm{q}_{\mathrm{m}}(\mathrm{mg} / \mathrm{g})$ & 0.60 & 0.22 \\
\cline { 2 - 4 } & $\mathrm{K}_{\mathrm{L}}(\mathrm{L} / \mathrm{mg})$ & 0.62 & 1.33 \\
\cline { 2 - 4 } & $\mathrm{R}^{2}$ & 0.94 & 0.94 \\
\hline \multirow{2}{*}{$\begin{array}{l}\text { Freundlich } \\
\text { Isotherm }\end{array}$} & $\begin{array}{c}K_{F}(\mathrm{mg} / \mathrm{g}) \\
(\mathrm{L} / \mathrm{mg})^{1 / n}\end{array}$ & 7.61 & 2.27 \\
\cline { 2 - 4 } & $\mathrm{R}^{2}$ & 0.90 & 0.88 \\
\hline
\end{tabular}


$1037.70,916.19,873.75,796.6,711.73,694.37$, $520.78,470.63,424.34)$ and $\mathrm{Cu}$ (II) loaded sample $(3628.10,873.75,796.60,694.37,520.78$, $470.63)$, a lot of increase and decrease in transmission (T\%) of the band was detected. In the $\mathrm{Pb}$ adsorption the band $3545.16 \mathrm{OH}-, 1795.73 \mathrm{C}-\mathrm{H}$ and 669.3 Si-O-Al disappear and in the $\mathrm{Cu}$ adsorption the band at $3545.16 \mathrm{OH}-, 711.73 \mathrm{Si}-\mathrm{O}$ and 669.3 $\mathrm{Si}-\mathrm{O}-\mathrm{Al}$ disappear, which enhanced the adsorption of these metals in bentonite clay.

\section{CONCLUSIONS}

The adsorptions to the copper and lead ions from polluted water on bentonite clay were based on $\mathrm{pH}$ and best removal was achieved at $\mathrm{pH}$ 5. The ideal concentrations with maximum removal efficiency for the $\mathrm{Pb}^{+2}$ and $\mathrm{Cu}^{+2}$ ions were achieved at $10 \mathrm{ppm}$. The removal capacity increased along with contact time and the appropriate adsorption times are $30 \mathrm{~min}$. The adsorption data were defined well with the Freundlich and Langmuir isotherms. The Langmuir model was fitted well for the adsorption of metal ions, and showed monolayer adsorption of the lead and copper ions. The FTIR analysis showed that the $\mathrm{OH}^{-}$stretching was greatest functional group accountable on the adsorption of heavy metals. The outcomes of this work showed that bentonite is operative and alternate adsorbent to remove the lead and copper ions from aqueous solution due to low cost, ecological, and accessibility. While comparing the individual adsorption for $\mathrm{Cu}$ (II) also $\mathrm{Pb}$ (II) onto bentonite, it was found that the affinity for $\mathrm{Pb}$ (II) to interact with bentonite was higher than $\mathrm{Cu}$ (II).

\section{Acknowledgements}

The authors acknowledge the faculty and staff of the Sanitary Laboratory, College of Engineering, Mustansiriyah University (www. uomustansiriyah.edu.iq), to provide assistance for devices used in this research. The authors also acknowledge the German-Iraqi Laboratory,

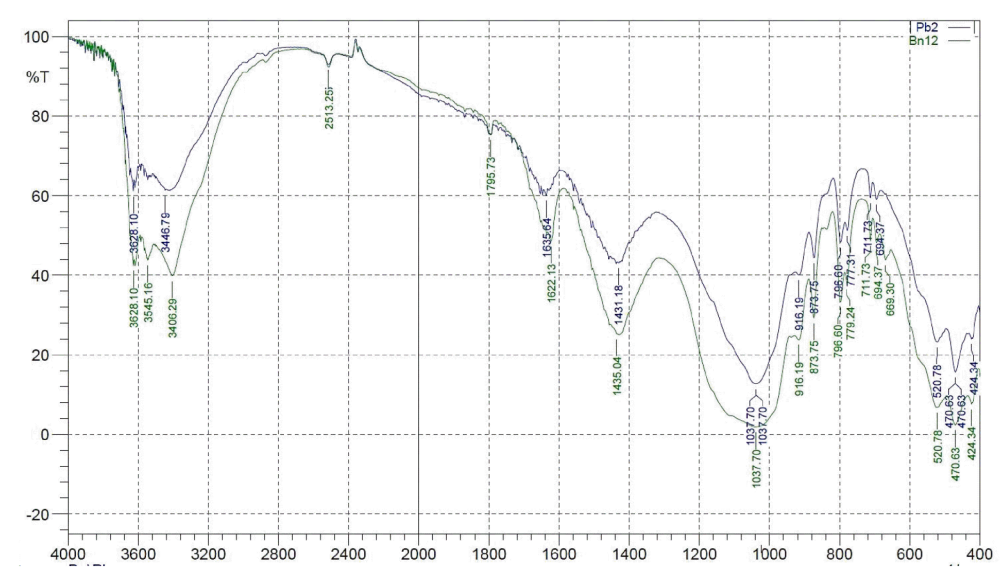

Figure 8. FTIR spectrum of Bentonite before and after adsorption by lead

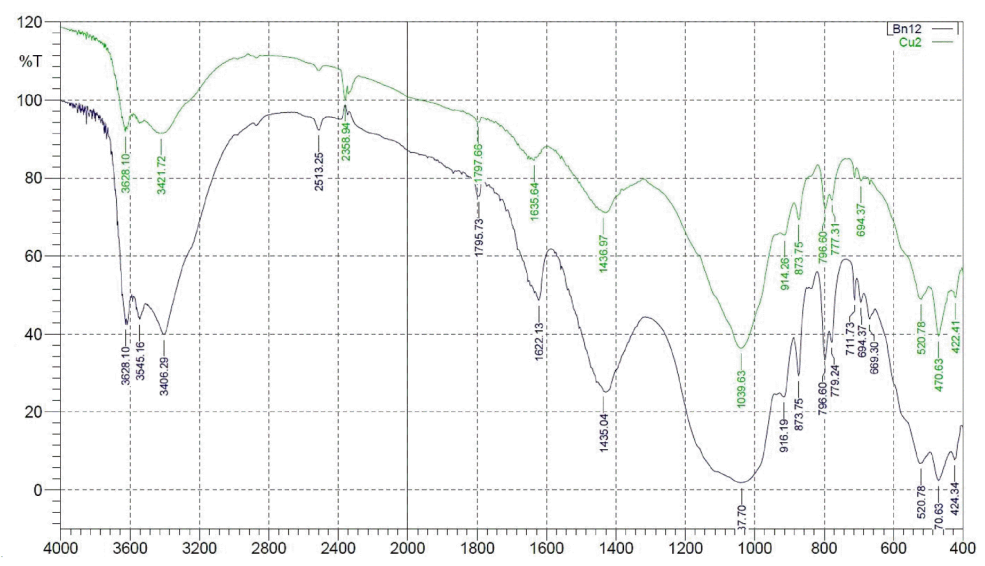

Figure 9. FTIR spectrum of Bentonite before and after adsorption by copper 
Baghdad University, and the Ministry of Science and Technology Laboratories, Environment and Water Research Department, for their assistance in conducting some of the tests used.

\section{REFERENCES}

1. Abbas M.N., Al-Madhhachi A.T., Esmael S.A. 2019. Quantifying soil erodibility parameters due to wastewater chemicals. Int. J. Hydrology Science and Technology, 9(5), 550-568.

2. Acharya J., Sahu J.N., Mohanty C.R., Meikap B.C. 2009. Removal of lead (II) from wastewater by activated carbon developed from Tamarind wood by zinc chloride activation. Chem. Eng. J, 149, 249262. https://doi.org/10.1016/j.cej.2008.10.029.

3. Benzaoui T., Selatnia A., Djabali D. 2017. Adsorption of copper (II) ions from aqueous solution using bottom ash of expired drugs incineration. Adsorption Science and Technology, 36(4), 026361741668509.

4. Bertagnolli C., Kleinübing S.J., Silva M.G.C. 2011. Preparation and characterization of a Brazilian bentonite clay for removal of copper in porous beds. Applied Clay Science, 53(1), 73-79. http://dx.doi. org/10.1016/j.clay.2011.05.002

5. Fu F., Wang Q. 2011. Removal of heavy metal ions from wastewaters: A review. J. Environ. Manage, 92, 407-418.

6. Galindo L.S., Neto A.F., da Silva M.G.C., Vieira M.G.A. 2013. Removal of Cadmium (II) and Lead (II) Ions from Aqueous Phase on Sodic Bentonite. Materials Research, 16(2), 515-527. DOI: 10.1590/ S1516-14392013005000007.

7. Gusain D., Srivastava V., Sharma Y. C. 2014. Kinetic and thermodynamic studies on the removal of $\mathrm{Cu}$ (II) ions from aqueous solutions by adsorption on modified sand. J. Ind. Eng. Chem., 20, 841-847.

8. Helena L., Chaves G., Tito G. A. 2011. Cadmium and copper adsorption on bentonite: effects of $\mathrm{pH}$ and particle size. Revista Ciencia Agronomica, 42(2), 278-284. DOI: 10.1590/ S1806-66902011000200004.

9. Hannachi Y., Homri T., Boubaker T. 2013. Utilization of Tunisian Bentonite as Ion-Exchange And Sorbent Material In The Removal Of Lead From Aqueous Solutions. The holistic approach to environment, 3(3), 123-140.

10. Inglezakisa V.J., Stylianou M.A., Gkantzoua D., Loizidoua M.D. 2019. Removal of $\mathrm{Pb}$ (II) from aqueous solutions by using clinoptilolite and bentonite as adsorbents. Desalination. 210(1-3): 248-256.

11. Jiang M., Wang Q., Jin X., Chen Z. 2009. Removal of $\mathrm{Pb}$ (II) from aqueous solution using modified and unmodified kaolinite clay. Journal of hazardous materials, 170(1), 332-9.

12. Karapinar N., Donat R. 2009. Adsorption behaviour of $\mathrm{Cu} 2+\mathrm{a} \mathrm{Cd} 2+$ onto natural bentonite. Desalination, 249, 123-129.

13. Lacin O. Bayrak B., Korkut O., Sayan E. 2005. Modeling of adsorption and ultrasonic desorption of cadmium (II) and zinc (II) on local bentonite. Journal of Colloid and Interface Science, 292(02), 330-335.

14. Melichova Z., Hromada L. 2012. Adsorption of $\mathrm{Pb} 2+$ and $\mathrm{Cu} 2+$ Ions from Aqueous Solutions on Natural Bentonite. Polish Journal of Environmental Studies, 22(2), 457-464.

15. Mnasri-Ghnimi S., Frini-Srasra N. 2019. Removal of heavy metals from aqueous solutions by adsorption using single and mixed pillared clays. Applied Clay Science, 179, 105151.

16. Mohan D., Pittman C. U. 2006. Activated carbons and low cost adsorbents for remediation of triand hexavalent chromium from water. J. Hazard. Mater, 137, 762 -811. https://doi.org/10.1016/j. jhazmat.2006.06.060.

17. Mutter G.M., Al-Madhhachi A.T., Rashed R.R. 2017. Influence of soil stabilizing materials on lead polluted soils using Jet Erosion Tests. International Journal of Integrated Engineering, 9(1), 28-38.

18. Nassef E., Mahmoud A., Salah H., El-taweel Y. 2017. Removal of Copper Ions from Liquid Wastes Using Adsorption Technique. Int. J. Res. Ind. Eng., 6(3), 522-562.

19. Neto A.F., Vieira M. G.A., Silva M.G.C. 2012. Cu (II) adsorption on modified bentonitic clays: different isotherm behaviors in static and dynamic systems. Materials Research, 15(1), 114-124.

20. Ogbu I.C., Akpomie K.G., Osunkunle A.A., Eze S.I. 2019. Sawdust-kaolinite composite as efficient sorbent for heavy metal ions. Bangladesh Journal of Scientific and Industrial Research, 54(1), 99-110.

21. Potgieter J.H., Potgieter V.S.S., Kalibantonga P.D. 2006. Heavy metals removal from solution by palygorskite clay. Clay Minerals Eng., 19, 463- 470. DOI: 10.1016/j.mineng.2005.07.004.

22. Ding S., Sun Y., Yang C., Xu B. 2009. Removal of copper from aqueous solutions by bentonites and the factors affecting it. Mining Science and Technology (China), 19(4), 489-492.

23. Ugwu I., Igbokwe O.A. 2019. Sorption of Heavy Metals on Clay Minerals and Oxides: A Review. Advanced Sorption Process Applications, Serpil Edebali, IntechOpen. DOI: 10.5772/intechopen.80989.

24. Zuzana, M., Michaela, H. 2015. Removal of $\mathrm{Cu}$ (II) Ions from Aqueous Solutions by Adsorption onto Natural Bentonites. Solid State Phenomena, 244, 205-212. DOI: 10.4028/www.scientific. net/SSP.244.205. 